\title{
Study links Zika virus to Guillain-Barré syndrome
}

\author{
Jacqui Wise
}

London

A study of patients who developed Guillain-Barré syndrome during an outbreak of Zika virus in French Polynesia has provided the first compelling evidence of a causative link between the virus and the syndrome. ${ }^{1}$

The researchers of the study, published in the Lancet, said that Zika virus should be added to the list of infectious pathogens that can cause Guillain-Barré syndrome. They warn that countries in Latin America affected by the current Zika epidemic should be prepared for an increase in the incidence of Guillain-Barré syndrome and ensure that they have enough intensive care beds.

Guillain-Barré syndrome is a rare neurological complication seen after a variety of bacterial and viral infections, such as campylobacter and cytomegalovirus infections. Around 100 000 people develop it every year worldwide.

Between October 2013 and April 2014 French Polynesia experienced the largest outbreak of Zika virus that had been described until then. An estimated 32000 patients consulted a doctor about a suspected Zika virus infection; and Guillain-Barré syndrome was diagnosed in 42 patients at the Centre Hospitalier de Polynésie Française in Tahiti.

All 42 of these patients were included in the current study and compared with two control groups. The first control group, matched for age, sex, and island of residence, consisted of 98 patients who attended the same hospital but did not have a fever. The second control group of 70 patients were age matched patients with acute Zika virus disease but no neurological symptoms.

Most (88\%) of the patients with Guillain-Barré syndrome reported symptoms of Zika virus infection around six days before the onset of neurological symptoms, but none tested positive for Zika virus infection once in hospital. However, of the 42 patients, 41 were carrying Zika virus antibodies, and all had neutralising antibodies against Zika virus. This compared with 54 of the 98 patients in the first control group.

Most (88\%) of the patients with Guillain-Barré syndrome had signs of past dengue virus infection, as did most patients in the two control groups ( $89 \%$ and $83 \%$ ). The researchers concluded that past infection with dengue virus did not increase the risk of Guillain-Barré syndrome among patients infected with Zika virus.

All 42 patients had a type of Guillain-Barré syndrome called acute motor axonal neuropathy, but few carried the biological markers typically associated with this type, indicating a previously unknown disease mechanism. The patients generally recovered faster than is usually expected with Guillain-Barré syndrome. Of the 42 patients, 16 were admitted to the hospital's intensive care unit, and 12 needed respiratory assistance. Their average length of stay in hospital was 11 days, but those who needed intensive care remained for an average of 51 days. Three months after discharge just over half of the patients were able to walk without assistance. No patients with Guillain-Barré syndrome died

Jimmy Whitworth, professor of international public health at the London School of Hygiene and Tropical Medicine, commented, "If the experience of Zika virus infection in Latin America is similar to that seen in French Polynesia, we can expect to see about 2-5 cases of Guillain-Barré syndrome for every 10000 people who get infected. This has implications for healthcare in countries with a Zika virus epidemic, as a proportion of those affected with Guillain-Barré syndrome will need breathing support on a ventilator for a while, and some [patients] do not recover fully from the syndrome and are left with disability."

Jeremy Farrar, director of the Wellcome Trust, said, "This study provides the most compelling evidence to date of a causative link between Zika virus infection and the serious neurological condition Guillain-Barré syndrome." He added, "The scale of the crisis unfolding in Latin America has taken us all by surprise, and we should be prepared for further unforeseen complications of Zika virus infection to emerge in the coming weeks and months."

1 Cao-Lormeau V-M, Blake A, Mons S, et al. Guillain-Barré syndrome outbreak associated with Zika virus infection in French Polynesia: a case control study. Lancet 2016;29. doi:10. 1016/S0140-6736(16)00562-6.

Published by the BMJ Publishing Group Limited. For permission to use (where not already granted under a licence) please go to http://group.bmj.com/group/rights-licensing/ permissions 